\title{
Formation of Angerh Minue Cave in Asmari Karst Complex of Zagros Mountain, Iran
}

Study Area: Fars, Iran

Ghassem Ghaderi ${ }^{1 *}$, Leila Karimi ${ }^{2}$

'Poorab Fars; Mehr Building. 44 La.Pasdaran Blvd., Shiraz, Fars, Iran

${ }^{2}$ Iran Speleology Society; 238 Building,. 8 La. Mahalati Av., Shiraz, Fars, Iran

Coordinates: $30^{\circ} 19^{\prime} 15.3^{\prime \prime} \mathrm{N}, 52^{\circ}$ o2' $38.5^{\prime \prime} \mathrm{E}$

Key words: Zagros Mountain, Cave formation.

\section{Abstract}

The Angerh Minue Cave, located in one $\mathrm{km}$ from west Angerh village which is about $97 \mathrm{~km}$ far from Shiraz of Fars Province, the Cultural Capital of Iran. The main entrance of the cave is at an altitude of 2430 having a depth of $176 \mathrm{~m}$ and length $776 \mathrm{~m}$. It developed along the bedding of limestone layers. Asmari Formation is the host rock of the Angerh Minue cave. Mountainous region of Zagros, where the Angerh Minue cave is located could be referred as seismic region due to the presence of various basement faults, some of which are still active. In the present study, the geological process behind the formation of Angerh Minue Cave has been tried to analyze.

\section{Introduction}

Zagros is a mountain range that extends from Turkey, Iraq to Iran, which is oriented from the northwest to the south Iran, and comprising nearly one fifth of the surface area of the country. Zagros, Elburz and central mountainous regions of Iran are mainly the karstic landscapes (Ghaderi \& Karimi, 2014). This region harbors many caves, till date many of which remain unexplored. All such caves which have been surveyed for bioinventory works in the present study are located in the central and southern parts of the Zagros Mountains.

With reference to the Angerh Minue Cave zone in the present study, we are reporting all the climatologic statistics, the geologic maps to the scale of 1:2500oo and topographic maps to the scale of 1:25000 (Topographic Maps). The geologic map to the scale of 1:2000 and structural maps including of faults, joints, dip and strike of layers, fold axis, were prepared on Google

*Corresponding Author: ghaderi1348@yahoo.com 
satellite images. Further, the same has been verified during the field operation where all the discontinuous surfaces including the fissures, fractures, faults and layering were measured coveringthe distance of one $\mathrm{km}$. The tabulated data were analyzed by the 'Rock Work' software. Besides it, all the discontinuous internal surfaces were defined by compass and analyzed by the relevant software. Mapping of the Angerh Minue cave was done by the members of Iran Speleology Society. Finally with the help of all the tectonic geologic, geomorphologic, climatologic and hydrogeological data and records we have tried to explain the formation and development of Angerh Minue Cave.

\section{Specification of Angerh Minue Cave:}

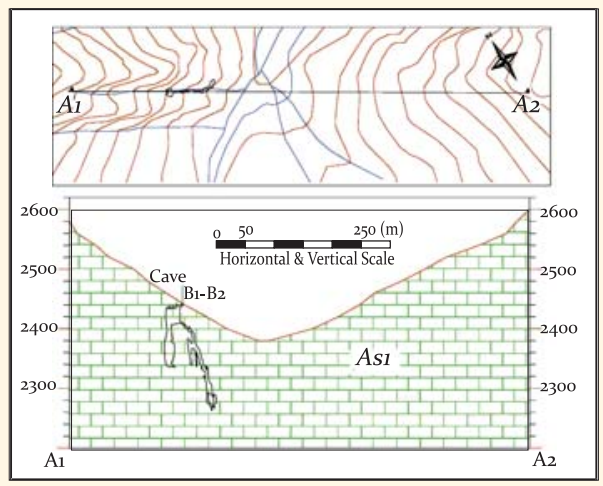

Geologic section (B1-B2) Angreh Minue Cave of Zagros Mountain is one of the outcomes of such karst complex which is surrounded by Minue Mountain in East, Siveh Mountain in South, Chahi Mountain in West and Talsorkhi in South. In the year 1985 this cave has been discovered by the members of Arsh Shiraz Mountaineering Club of Iran. The regional mean and minimal temperature of this particular area are 17 and $25^{\circ} \mathrm{C}$ in a statistical time of 35 years. Various tributaries of perennial River Angerh is flowing in that particular area which is irrigated by surrounding springs and tributaries of other rivers exist in the same Mountainous region.The regional mean precipitation which is mostly snowfall is $715 \mathrm{~mm}$ by virtue of the drawn isohyetal curves. The cave is form of dissolving limestone in which total eight wells with the depths of 10 to $60 \mathrm{~m}$ has developed along the bedding of limestone layers. The water move along the layering has prepared the first steps of karstif ication the limestone. Possibly the new entrances of the cave have appeared along the same layering. The annual mean temperature of the cave fluctuates in between 5 to $10^{\circ} \mathrm{C}$ round the year. Narrow corridors and cold water streams are other specifications of this cave.

\section{Ambient Stratigraphy and Lithology of the Cave:}

Angerh area is located in stratified Zagros landscape covering $150250 \mathrm{~km}$ width area.The Zagros fold and thrust belt was formed by collision of two tectonic plates the Eurasian (or Iranian) and Arabian Plates. As per Nilforoushan et al., (2003) the collision is still active and the resulting deformation is distributed disproportionately throughout the Iran. The trend of fold in Zagros is northwest southeast in which Paleozoic, Mesozoic and Triassic sediments are formed isoclinals. The outcrops found in the region include limestone (Asmari Formation), and marl (Razak Formation and Pabdeh-Gurpi Formation). Asmari Formation is the host rock of the Angerh Minue cave and due to various beddings and lithologic specifications it has been divided into four basic subformations (Darvishzadeh, 1992; Memarian, 1995). The lithostratigraphic units in the studied area in order to varioustimescales are as follows:

a) Pabdeh-Gurpi Formation (GU unit): This unit is the northwest wing of Kûh-eRonj 
mountain formed the central parts of Garah anticline and includes greenish gray marls with limestone and shale. In hydrogeologic view, this unit is impermeable and is a non-aquifer under Asmari permeable formation. This unit has northwest southeast trend and 28 - 15 degree dip towards northeast.The formation is of Paleocene- Oligoceneage.

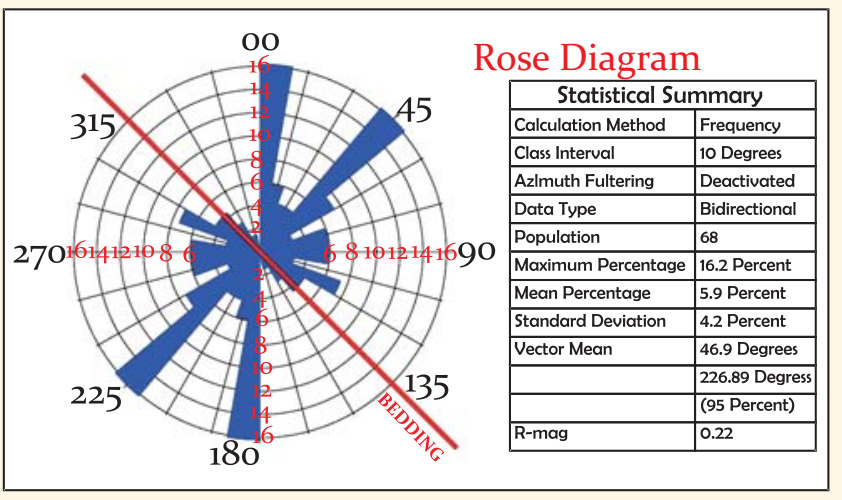

b) Asmari Formation ( $\mathrm{AS}_{1}, \mathrm{AS}_{2}, \mathrm{AS}_{3}$,

AS4 unit) : Asmari Formation is situated between the impermeable upper Gachsaran and lower Pabdeh-Gurpi Formations (Karimi et al., 2005). Asmariı which is the host rock of the cave includes light gray and white crystallized limestone of medium to thick beds, is composed of various fissures, cracks, and superficial karrens. Its potential for karstification is more than other contemporary units. During the study we concluded that the displacement of the bedding in these limestone and the tension faults parallel to the bedding played an important role during the cave formation. The mass slide from this unit could be easily recognized in Chahi Mountain (Asmari2), separated from upper heights and settled on Gurpi marls. Asmariz includes milky white limestone its resistance is less than Asmaris unit 1\&4. Asmari4 includes limestone with white and creamy thin and thick alternate layers under Razak Formations. The Asmari Formation in the studied area has northwest southeast trend and 85 - 15 degree dip. The slope is towards northeast in normal layers and southeast in returned layers. The return layers are only because of the faults. The formation is of Oligocene- Miocene age.

c) Razak Formation (RZ unit): it includes green and red marls with secondary layers of sandstone and gypsum. As per hydrogeological point of view this formation is having low permeability and resistance and is highly erosive. This is testif ied by the presence of hilly land outcrops. It is of Lower Miocene age.

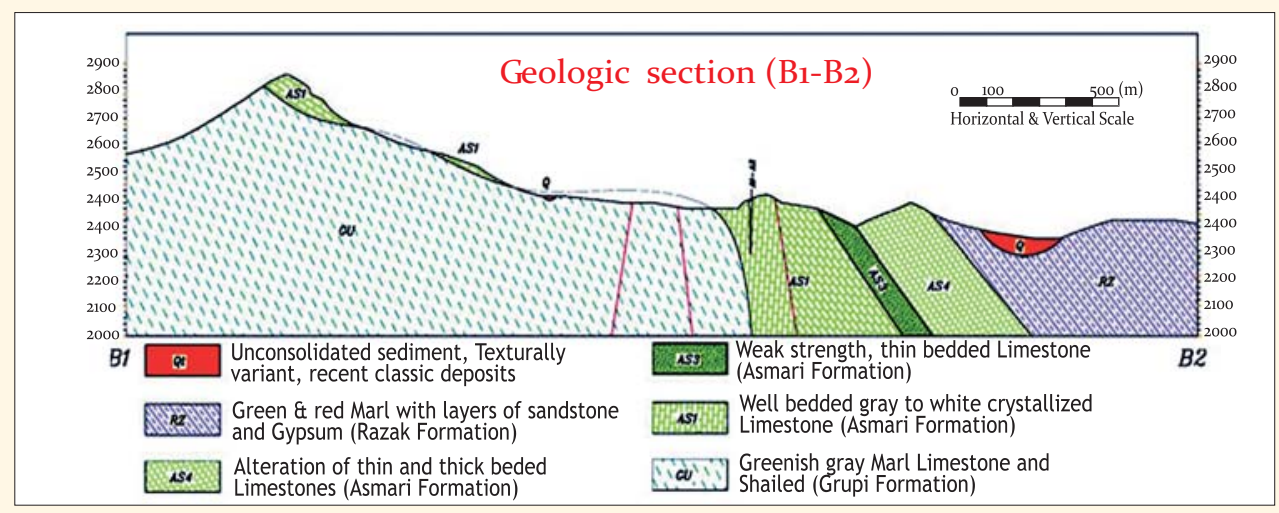




\section{Structural Tectonic Specifications:}

Mountainous region of Zagros, where the Angerh Minue cave is located could be referred as seismic region due to the presence of various basement faults, some of which are still active. Folding in the region evidenced to be appeared in Pliocene and Pleistocene with Pasadnian Oroegenic phase simultaneously and created a series of parallel anticlines and synclines with northwest southeast trend. The maximum forces on such structures have northeast southwest and are almost perpendicular to the folds axis. Of the regional folded structures we can mention Gero anticline in west and Angreh syncline in east with northwest southeast process in the same direction of general structures.

Several faults which had an important role in present Earth formation are visible in this region. Among them, the northwest southeast ones formed parallel to the bedding played an important role in the tension zone and the cave formation. The Rose diagram drawn for the regional faults shows two groups of shear faults and the bisector of the acute angle between them indicating the maximal forces is northeast southwest and is almost perpendicular to the bedding and folds axis. The cave entrance is on the northeast wing of Kûh-eRonj Mountain. This wing had been a reversed one and has the slope of 65 - 70 degree towards 230 - 235 degree $\mathrm{N}$. The appeared saddle like structures around the cave mountain is mostly created because of the change in lithology or in the thickness of the calcareous bedding. In addition, some shear zone layers have been seen especially near the entrance which increased the porosity in the bed.

Conclusively, The cave creation region is in the Zagros folded zone with the same structural and tectonic specifications; the Oligocene calcareous stones which belong to Asmari formation are the host stone of the cave and by virtue of the structural and lithology specifications it has the karstification potential in which the cave developed . The bedding, two setes of shear faults and the faults parallel to bedding were effective in the cave creation

\section{Acknowledgements}

We thank to our colleagues of Spelunkers' Society, Iran specially Mr. Yoossef Vaghef, Mr. Ebrahim Zaki, Mr. Majid Zaravandi and Mr. Amir Jelvani and Ms. Fatemeh Vaghef and Ms. Mitra Masoudi who drew the cave map and also the Mountain Climbing \& Sportive Mounting Society of Fars Province specially Mr. Mohammad Karimi and Mr. Amir Hossain Noori because of their honest and diligent cooperation and efforts

\section{References:}

Darvishzadeh A. (1992): Geology of Iran. Danesh-e Emrooz Publication. Related to Amirkabir Publication Organization, 873p.

Karimi H., Raeisi E., \& Bakalowicz M. (2005): Characterizing themain karst aquifers of the Alvand basin, northwest of Zagros, Iran, bya hydrogeochemical approach: Hydrogeology Journal, 13: 787-799.

McQuillan H., Roohi M. \& Evers H.J. (1978): Ardakan Geological map scale 1:10oooo, 1978, National Iranian Oil Company, Tehran

Memarian H. (1995): Engineering \& Geotechnical Geology, Tehran University Press .

Nilforoushan F., Masson F., Vernant P., Vigny C., Martinod J., Abbassi M.,Nankali H., Hatzfeld D., Bayer R., Tavakoli F., Ashtiani A.,Doerflinger E. , Daignières M., Collard P., \& Chéry J. (2003): GPS network monitors the ArabiaEurasia collision deformation in Iran. Journal of Geodesy, 77: 411-422 